Mgr Jerzy Skwarzyński

UMCS Lublin

e-mail: jerzy.skwarzynski@gmail.com

\title{
What Makes Tushman Funny? The Polish Version of the Young Adult Novel Wonder by R.J. Palacio as an Example of Fair Translation
}

There are few subsections of literature that would allow so much freedom upon translation as children's fiction ${ }^{1}$. For that reason, translators usually choose to create translations that are closer to the culture of target readers and thus easy to read rather than faithful to the original ${ }^{2}$. This approach may result in distorting the message of the story, changing emotional charge of the events, or creating a character that is very different from what the original author intended.

A good example of such alteration is the German version of Astrid Lindgren's Pippi Langstrump published in 1965. In one scene, Pippi finds pistols in the attic and, instead of handing them to her friends to play with as she does in the original, she puts them back into the chest, proclaiming that weapons are not toys. Such responsible behaviour is the exact opposite of what Pippi represents; the decision to change this scene was probably made lest it inspired violence among young readers in post-war Germany ${ }^{3}$.

Erich Kästner's Emil und die Detektive and three of its translations provide another illustration of changing the content of the story in translation to make the it more "appropriate" for the target audience. The story is set in the Berlin of the Weimar Republic and is permeated with nostalgia for that era. Nevertheless, in one Swedish translation Berlin transforms into Stockholm, in the first Hungarian ver-

1 Z. Shavit, Translation of Children's Literature, [in:] The Translation of Children's Literature, ed. G. Lathey, Clevedon: Multilingual Matters 2006, pp. 25-40.

2 T. Puurtinen, Translating Children's Literature: Theoretical Approaches and Empirical Studies, [in:] The Translation of Children's Literature..., pp. 5-64.

3 E. O'Sullivan, Narratology Meets Translation Studies, or The Voice of the Translator in Children's Literature, [in:] The Translation of Children's Literature ..., pp. 98-109. 
sion into Pest, and in the Polish rendition into Kraków ${ }^{4}$. Those translations provide the readers with a story devoid of its original setting, which is an integral element of the source text. Readers of those translations are presented with a book that is very different from the original Emil.

Examples of such alterations can be listed without end. The reason for those changes is, in their creators' minds, to make the translated text "better" or "more accessible" for the target audience. Does depriving young readers of facing the unknown, of dealing with the cultural unfamiliarity and of challenging their preconceptions really benefit them?

Considering translation as means to show the unknown to the recipients inevitably leads to more radical methods characteristic to postcolonial studies, e.g. footnotes or annotations. These are usually frowned upon, especially in children's books. Even though some scholars believe that children have the ability to comprehend some traces of the unfamiliar, they argue that footnotes should not appear in texts for young readers ${ }^{5}$. They are often considered an invasive tool that hampers the reception and discourages young people from reading. As some of the examples below show, footnotes can in fact facilitate the understanding of the story.

Nevertheless, this paper is not merely praise of footnotes or other translation tools advocated by postcolonial studies. Contrarily, it aims to show that translating should not be ideology-driven. The translator's goal is to provide the young reader with what I call a fair translation: a target text (TT) that is likely to evoke a reaction similar to that elicited by the source text (ST) among its readers. To that end, the translator is free to use a variety of translation tools so that the reader of the TT is provided with the same information as the reader of the ST and that the TT reader has been given the ability to react in the same or at least similar way as the ST reader. Thus, a fair translation is one that exposes its reader to the intellectual and emotional stimuli as close to that of the ST as possible. A fair translator tries to ensure that the ST reader and the TT reader look at the story from almost the same position. To achieve that, a plethora of translation strategies on the microlevel must be employed.

The goal of this paper is to highlight the importance of fair translation and to exemplify it by means of analysing some translation decisions in extracts from the Polish version of Wonder, a young adult novel by R.J. Palacio published in 2012. The book tells the story of a ten-year-old August, who was born with a severely deformed face. For the first part of his life he was homeschooled by his mother; he is now going to school for the first time. In this new environment he is welcomed and understood by some, yet treated with hostility and prejudice by others. The

\footnotetext{
${ }^{4}$ G. Lathey, Translating Children's Literature, Abingdon: Routledge 2016, p. 38.

5 Ibidem, pp. 37-54.
} 
only existing translation of Wonder into Polish was done by Maria OlejniczakSkarsgård and first published in 2014.

The book features numerous references to American civilisation and is steeped in the US culture, which poses a number of translation challenges. Inasmuch as most of the young English-speaking readers are likely to understand the references to the Anglophone culture easily and react to them accordingly (e.g. with amusement while reading humorous parts), those connotations might confuse foreign readers and thus evoke reactions different to those of the readers of the original.

Olejniczak-Skarsgård did not try to pretend that Wonder was originally written in Polish. She made it abundantly clear that her version was embedded in Anglophone culture and that it was a translation. Nevertheless, she produced it in a way that treats the TT readers fairly. They are provided with the same or at least similar input as the ST readers and thus have a chance to react similarly. Below are selections from the novel that illustrate how it was done using a number of different solutions. As this study focuses on translation issues originating from cultural differences, only the excerpts that display strong links to the ST culture were chosen for this discussion. They were selected so that every translation solution applied to culture-based issues that are present in the book could be addressed.

For clarity and coherence of the argument, a defined, cogent list of translation solutions had to be referred to. I used the categorisation suggested by Roman Lewicki in his recent monograph Zagadnienia lingwistyki przektadu (Aspects of the Linguistics of Translation).

The TT readers may be familiar with the original text's culture-specific items that exist in their cultural sphere. These may include titles, names of characters or objects from internationally famous texts of culture, such as "Peter Pan" (W: 73), "Captain Hook" (ibid.), "Star Wars" (W:8), "lightsaber" (ibid.), etc. In translation, these elements became their existing equivalents ${ }^{6}$ in the Polish version: "Piotrus Pan" (CCh: 104), "Kapitan Hak" (ibid.), "Gwiezdne wojny" (CCh: 18), "miecz świetlny" (ibid.) respectively. I can see no reason why a translator who aims to produce a readable, honest translation would try applying any other solution in this case.

Nevertheless, there are some cultural notions that appear or are referred to in Wonder that are not so easy to substitute with their Polish equivalents, even though they may be known to the TT audience. For example, the title of one chapter reads "The Padawan Bites the Dust" (W: 97), which is a blend of two cultural items. In the Star Wars franchise, "Padawan" denotes a Jedi knight apprentice ${ }^{7}$. Another One

${ }^{6}$ R. Lewicki, Zagadnienia lingwistyki przekładu, Lublin: Wydawnictwo UMCS 2017, p. 249.

7 Wookiepedia, Padawan, [online]. Available on the internet: http://starwars.wikia.com/ wiki/Padawan [accessed: 1 March 2018]. 
Bites the Dust is a 1980 single by Queen, a British rock band ${ }^{8}$. That chapter title in Wonder is probably supposed to amuse the readers, as "The Padawan" sounds very similar to "Another one" and both phrases have the same number of syllables; the title can be read or intonated to the melody of the famous song, which is an added value if the book is read aloud to a young recipient'. What is more, it brings the readers closer to the protagonist, as August adores everything connected to Star Wars and he listens to British rock.

In the Polish version, the same chapter is called "Padawan idzie w odstawkę" (CCh: 136), which includes an idiom and means "The Padawan is out". The reference to the song was omitted ${ }^{10}$. To see that this loss is not a dramatic one, let us consider other possible solutions in the context of the function of this passage.

In general, songs are seldom translated (those from the Disney films make a noteworthy exception), so there is no existing Polish equivalent of the song title that could be used. Trying to find a name of a Polish song, or at least a line from one, that would not only have a meaning similar to the phrase "another one bites the dust" but also could have a fragment of it replaced with the word "Padawan" so that it makes sense and sounds as well as it does in the original would be a rather daunting challenge, but even if it was accomplished, the reference to any Polish song in a story about a ten-year-old from Manhattan would be puzzling to say the least. The title of the chapter is intended to be humorous, so any attempt to explain it within the text would be counterproductive. Finally, the dreaded footnote, the translator's last resort, would probably make up for the absence of the cultural reference in the Polish version of the title. Would it be necessary in this case? One probably would not like the reader to spend time discovering multiple layers of cultural significance of a chapter title. Even though a reference is lost in this particular instance, August's flair for British rock is manifested throughout the book on many occasions. If one also considers that the suggested solution provides us with the same information and grounding as the original and makes the reading process flow, Olejniczak-Skaarsgard's translation seems as fair as it could be.

In most instances, however, cultural references in Wonder were preserved. The TT readers are likely to understand many of them due to the popularity of different items from the ST culture - one can assume that young Polish readers know what Manhattan is. Moreover, some notions can be self-explanatory. For example, a "late pass" (W: 18) was translated as "przepustka dla spóźnionych" (CCh: 31) which literally means "a pass for the late". It is mentioned in a book as something that a school secretary issues to the students who do not appear in school on time.

8 Wikipedia, Another One Bites the Dust, [online]. Available on the internet: https:// en.wikipedia.org/wiki/Another_One_Bites_the_Dust [accessed: 1 March 2018].

${ }^{2}$ Cf. G. Lathey, op. cit., pp. 93-111.

10 R. Lewicki, op. cit., p. 261. 
The notion of such a pass is unfamiliar to Polish students, as not only do they not have to address a school secretary to obtain it, but they also do not need any document regarding their lateness at all. Nevertheless, what a late pass is seems obvious from the context and does not require any explanatory techniques. By means of translator's neologism ${ }^{11}$, which falls into a wide category of foreignisation ${ }^{12}$, the translator exposes the reader to the unfamiliar, but, in this case, the text is fully understandable even though a new cultural notion appears.

Be that as it may, some culture-specific items and the meaning they carry can be more taxing in the Polish version. One of translation solutions resolving that problem in an unobtrusive way is what Lewicki calls descriptive translation or periphrasis, which he defines as explaining a ST term with a longer chain of words ${ }^{13}$. I find a bit broader term "in-text explanation" more applicable, as it refers to more than a single word and allows adding extra information to the existing notion (rather than just explaining that notion) to make the cultural allusion clearer. The following excerpt is a good example of this strategy.

Meanwhile, Mom's regular doctor wasn't on duty that night, so Mom got stuck with this cranky kid doctor she and Dad nicknamed Doogie after some old TV show or something (they didn't actually call him that to his face). (W: 6)

Ponieważ opiekujący się mamą lekarz akurat miał wolny dzień, musiała się zdać na jakiegoś podenerwowanego młodego doktorka, któremu dała z tatą przezwisko Doogie, zdaje się dlatego, że przypominal im się bohater serialu telewizyjnego Doogie Howser, lekarz medycyny (oczywiście nie zwracali się do niego tak bezpośrednio). (CCh: 16)

The sitcom in question was aired in the early 90s and, even though it was relatively esteemed at the time (it received Emmy Awards and a Golden Globe nomination ${ }^{14}$ ), it is now considered slightly obsolete ${ }^{15}$ and rather unpopular ${ }^{16}$. The translator decided to make it clear that "Doogie" was a name of a main character of a TV show past its prime and to provide its full title. This makes the reference

11 Ibidem, p. 251.

12 Cf. L. Venuti, The Translator's Invisibility, Abingdon: Routledge 2008, DOI: https:// doi.org/10.4324/9780203553190.

13 R. Lewicki, op. cit., p. 252.

14 Filmweb, Doogie Howser, lekarz medycyny, [online]. Available on the internet: http:// www.filmweb.pl/serial/Doogie+Howser\%2C+lekarz+medycyny-1989-93993/awards [accessed: 10 March 2018].

15 M. Springer, Doogie Howser, M.D., [online]. Available on the internet: https://www. commonsensemedia.org/tv-reviews/doogie-howser-md\# [accessed: 10 March 2018].

${ }^{16} \mathrm{IMDb}$, Doogie Howser, lekarz medycyny, [online]. Available on the internet: http://www. imdb.com/title/tt0096569/ [accessed: 10 March 2018]. 
less vague without revealing the joke hidden in it: that the main character of the show to whom August's mother's doctor is compared is a teenager. I believe it is safe to assume that neither a Polish or American twelve-year-old would understand that connotation. Nevertheless, if they wanted to decode it, making the source of the reference simpler might have been a good idea. If the young reader asks their parents for clarification, it is more possible that an American adult is able to connect the name "Doogie" with a particular TV show than a Polish one. Thus, the in-text explanation in the translation gives the TT reader the ability to discover the meaning of the joke comparable to that of the ST reader. Both readers are fairly put on the same position.

Some scenes in Wonder were built around culture-specific items. Since a fair translator attempts to create a version that depicts the reality of the translated text in the way similar to that of the original, these references must stay unchanged. To facilitate their reception, footnotes ${ }^{17}$ can be used. The below fragment of a friendly conversation between August and his new friend named Summer is one of those instances.

Hey, our names kind of match," she said as she chewed.

I guess she could tell I didn't know what she meant.

"Summer? August?" (W: 52)

—Zauważyłeś, że nasze imiona pasują do siebie? — spytała, przeżuwając.

Chyba zorientowała się, że nie wiem, o co jej chodzi.

- Summer... August*...

*Summer (ang.) - lato, także imię żeńskie; August (ang.) - sierpień, także imię męskie. (CCh: 75)

Any literate English-speaking person can instantly understand and appreciate the pun from the original. It cannot be expected from Polish tween or possibly teen readers - not everybody must study English after all. The translator solved the readers' potential confusion by adding brief and clear footnotes which explain the double meaning of the English words. That solution brought the TT readers to the ST readers' level of understanding.

Alternatively, the names could be naturalised, i.e. replaced with Polish names of double meaning, such as "Róża" and "Wawrzyniec". Then, the connection between the two would be the fact that both refer to plants ("Róża" means "Rose", "Wawrzyniec" comes from "wawrzyn" which is "laurus"), but how one would explain why two American children with no Polish ties living in New York have

17 R. Lewicki, op. cit., p. 253. 
rather uncommon Polish names? That solution would add incoherent cultural links that are not present in the original and have no justification in the Polish version.

Another potential solution would be to add periphrasis, but it would have to be rather lengthy and clumsy; besides, few things kill jokes more indiscriminately than spelling out why they are funny. The reference could also be deleted, but that would result in deleting the entire scene (which in this case is nearly the whole chapter that is referred to later on in the book). The translator could also leave the Polish text as it was, risking lack of comprehension on the readers' part. That would be unfair; without footnotes, the TT readers would not be able to react in the same way the ST readers could.

There is yet another possibility, which I want to mention briefly just for the sake of exhausting all theoretically plausible options as I find it hard to believe that anyone would like to recognise it in practice: translating the names literally, i.e. "Summer" into "Lato" (name of the season) and "August" into "Sierpień" (name of the month). Firstly, these words do not function as names in Polish (which alone is enough to rule them out). Secondly, this solution would not make the joke funny, as puns require double meaning of words.

Summer's remark inspires her and August to create a Summer Table - a table in school cafeteria at which only children with summer-related names would sit. They started preparing a list of candidates, which brings me to the next translation challenge and yet another translation solution - approximation ${ }^{18}$, which is a rather radical solution that represents a more general translation approach called naturalisation or domestication ${ }^{19}$.

There's a kid named Reid in my English class," I said.

"Yeah, I know Reid, but how is Reid a summer name?" she asked.

'I don't know." I shrugged. "I just picture, like, a reed of grass being a summer thing." (W: 52)

W mojej grupie na angielskim jest Leo.

— Znam go. Ale dlaczego Leo kojarzy ci się z latem?

— Bo ja wiem? - Wzruszyłem ramionami. - Wyobrażam sobie lwa, a lwy mieszkają w Afryce, gdzie jest ciepło. (CCh: 75-76)

This short extract from the original is filled with cultural references: the name "Reid", nonexistent in Poland; the fact that its pronunciation is similar to "reed", which in Polish is "trzcina"; finally, that a "reed of grass" relates to summer in some

\footnotetext{
18 R. Lewicki, op. cit., p. 255.

19 Cf. L. Venuti, op. cit.
} 
way. This challenge could be solved effectively by means of a footnote, but the translator devised a smoother, less "invasive" solution that reads well and transfers the cultural references in a clear way. By renaming the boy, the translator kept the element of American culture, since "Leo" functions as a name in the Anglophone culture. Moreover, the word's clear zoological link made it possible for an average Polish reader to understand the connection between "Leo" and "lion" ("lew" in Polish) and its loose association with summer (lions live in Africa where it is warm), so similar to that in the original.

The last example is a series of extracts that, to my estimation, are the most perspicuous example of an effective mixing of different solutions applied not only in the same scene, but to the same translation problem. At the beginning of the novel, August's parents talk to him about going to school for the first time. The boy is apprehensive of the idea. His dad tries to convince him to meet with the school principal, Mr. Tushman.

"How about this? Can you at least meet Mr. Tushman before making up your mind?" Mom asked.

"Mr. Tushman?" I asked.

"He's the principal," answered Mom.

"Mr. Tushman?" I repeated.

"I know, right?" Dad answered, smiling and looking at me in the rearview mirror. (p. 13)

— Może przynajmniej spotkałbyś się z panem Tushmanem* przed podjęciem decyzji? Co ty na to?

- Z panem Tushmanem?

— Wicedyrektorem — wyjaśniła mama.

- Naprawdę się tak nazywa?

— Dobre, co? — wtrącił się tato i z rozbawioną miną spojrzał na mnie w lusterku wstecznym.

*Tush (w amerykańskiej angielszczyźnie) - tyłek, zadek. Man (ang.) - człowiek, mężczyzna. (p. 25)

The surname "Tushman" could not be naturalised for the same reasons as those regarding the names of Summer and August. A readable periphrasis would be very hard, or even impossible, to add in a natural way into the dialogue. Omission would ultimately result in deleting the whole chapter and would cause a considerable plot hole. An equivalent does not exist. Leaving the surname with no comment would cause confusion rather than amusement. A brief footnote breaking down the meaning of "Tushman" and thus justifying August's surprise seems to be the only fair solution. 
In the following fragment, August's dad tries to use the principal's name to make the boy laugh:

"Auggie, you know, you should go to that school just so you can hear his name said over the loudspeaker!" Dad said excitedly. "Can you imagine how funny that would be? Hello, hello! Paging Mr. Tushman! I see you're running a little behind today! Did your car get rear-ended again? What a bum rap!"’" (p. 13)

— Wiesz, Auggie, warto zostać uczniem tej szkoły choćby po to, żeby słyszeć te wszystkie żarty z jego nazwiska! — ciągnął podekscytowanym głosem. — Pomyśl sobie, ile będzie zabawy. „Uwaga, uwaga! Pan Dupman proszony jest na posiedzenie”. - Tato naśladował wysoki głos starszej pani. - (b) „Pan Dupman może odebrać duplikaty dokumentów”. (p. 25)

All of the sudden, "pan Tushman" turns into "pan Dupman" in the Polish version. What looks like incoherence is in fact a witting adjustment of translation solutions dictated by the attempt to evoke a reaction similar to that of the ST reader. Once the double meaning behind "Tushman" is clarified, the translator allows herself to naturalise the following part of the scene to evoke immediate amusement just like the original does.

Another interesting observation is that there are more puns in the original than in the translation. Arguably, it is more difficult to find words or phrases in Polish that could refer to a bottom and have a double meaning. The number of the jokes is not crucial, as long as the general idea was preserved and a similar intellectual or emotional reaction evoked ${ }^{20}$.

The scene continues:

Mommy and I had a professor in college called Miss Butt.

$[\ldots]$

"Hey hey, I know!” said Dad excitedly. "Let's fix them up on a blind date! Can you imagine? Miss Butt, meet Mr. Tushman. Mr. Tushman, here's Miss Butt. They could get married and have a bunch of little Tushies." (p. 13-14)

Gdy byliśmy z mamą w college'u, uczyła nas niejaka pani Butt*.

*Butt (ang.) - tyłek, zadek.

[...]

— Słuchajcie, mam pomysł! — zawołał tato. - A gdyby tak umówić ich na randkę w ciemno? Wyobrażacie to sobie? „Pani Tyłeczek, to jest pan Dupman”. „Panie Dupman, oto pani Tyłeczek". Z czasem by się pobrali i mieli gromadkę małych Dupmanków. (p. 25-26)

${ }^{20}$ Cf. U. Eco, Mouse or Rat? Translation as Negotiation, London: Phoenix 2003, pp. 32-61. 
When a new surname appears, the translator goes back to footnoting once more, but, again, she goes on to naturalise the jokes that August's dad makes of the surnames "Tushman" and "Butt". Due to applying diverse solutions, the scene in translation is as understandable, culturally logical and funny to the young readers as the original is.

The above examples illustrate that it is indeed possible to create a coherent, readable and fair translation by using a range of solutions, or even that, in some cases, the use of different solutions is imperative to produce such a translation. Another conclusion is that footnotes can facilitate the reception as long as they are clear, short and sparse. Even though I do not believe that a footnote as such hinders the reception of a text, I think that overusing this tool might. One should use footnotes in translating for children only if no other strategy would produce a fair translation.

To support these conclusions, however, an empirical research regarding young readers' attitude towards how elements of ST culture are transferred in translation is required. Such empirical studies are pivotal in raising translators' awareness of differences between cultures and languages, in discussing effective ways of rendering them and in indicating the importance of fair translation.

\section{Streszczenie}

\section{Dlaczego Tushman jest śmieszny? Polska wersja powieści dla młodzieży pt. Wonder R. J. Palacio jako przykład uczciwego thumaczenia}

Uczciwe thumaczenie to takie, którego rezultatem jest tekst docelowy wywołujący u czytelników reakcję zbliżoną do tej powodowanej przez tekst wyjściowy. By temu podołać, tłumacz musi mieć możliwość wykorzystania dowolnych rozwiązań translacyjnych na poziomie jednostkowym i całościowym. Polskie tłumaczenie powieści dla młodzieży Wonder autorstwa R.J. Palacio opracowane przez Marię Olejniczak-Skarsgård jest tego dobrym przykładem. Pojawiające się w niej problemy translacyjne zostały rozwiązane dzięki różnym strategiom. W wyniku połączenia rozmaitych rozwiązań powstał klarowny przekład, który umożliwia odbiorcy zareagowanie na opowieść i jej elementy tak jak czytelnikowi oryginału. Przeprowadzona analiza daje podstawy do badań empirycznych dotyczących stosunku młodych odbiorców do paratekstów.

Słowa kluczowe: uczciwe tłumaczenie; tłumaczenie literackie; przypisy; paratekst; przekład literatury dziecięcej; literatura młodzieżowa

\section{Summary}

Fair translation is one that results in producing a target text that is likely to evoke a reaction similar to that elicited by the source text among its readers. The translator's goal is to provide the readers of the translated version with the stimuli as close to that of the original 
as possible. To ensure that, the translator must be free to use every solution they find appropriate on micro- and macrolevel. Olejniczak-Skarsgård's Polish translation of the young adult novel Wonder by R.J. Palacio is a good example of such rendition. A number of translation challenges was dealt with by very diverse translation strategies. Combining approaches resulted in a readable target text that has the potential to provoke the same reaction as the original. This analysis can be followed by empirical studies regarding young readers' reception of paratextual additions.

Keywords: fair translation; literary translation; footnotes; paratext; translation of children's literature; young adult literature

\section{Bibliography}

Eco U., Mouse or Rat? Translation as Negotiation, London: Phoenix 2003.

Filmweb, Doogie Howser, lekarz medycyny, [online]. Available on the internet: http://www. filmweb.pl/serial/Doogie+Howser\%2C+lekarz+medycyny-1989-93993/awards [accessed: 10 March 2018].

IMDb, Doogie Howser, lekarz medycyny, [online]. Available on the internet: http://www. imdb.com/title/tt0096569/ [accessed: 10 March 2018].

Lathey G., Translating Children's Literature, Abingdon: Routledge 2016.

Lewicki R., Zagadnienia lingwistyki przekładu, Lublin: Wydawnictwo UMCS 2017.

O'Sullivan E., Narratology Meets Translation Studies, or The Voice of the Translator in Children's Literature, [in:] The Translation of Children's Literature, ed. G. Lathey, Clevedon: Multilingual Matters 2006, p. 98-109.

Palacio R.J., Wonder, London: Corgi 2014.

Palacio R.J., Cud chłopak, trans. by M. Olejniczak-Skarsgård, Warszawa: Wydawnictwo Albatros 2014.

Puurtinen T., Translating Children's Literature: Theoretical Approaches and Empirical Studies, [in:] The Translation of Children's Literature, ed. G. Lathey, Clevedon: Multilingual Matters 2006, pp. 54-64.

Shavit Z., Translation of Children's Literature, [in:] The Translation of Children's Literature, ed. G. Lathey, Clevedon: Multilingual Matters 2006, pp. 25-40.

Springer M., Doogie Howser, M.D. [online]. Available on the internet: https://www.commonsensemedia.org/tv-reviews/doogie-howser-md\# [accessed: 10 March 2018].

Venuti L., The Translator's Invisibility, Abingdon: Routledge 2008, DOI: https://doi. org/10.4324/9780203553190.

Wikipedia, Another One Bites the Dust [online]. Available on the internet: https://en.wikipedia.org/wiki/Another_One_Bites_the_Dust [accessed: 1 March 2018].

Wookiepedia, Padawan, [online]. Available on the internet: http://starwars.wikia.com/wiki/ Padawan [accessed: 1 March 2018]. 